\title{
Microdialysis in vivo evaluation of the effects of SA-4503, a sigma1 receptor agonist, on the levels of monoamines in the prefrontal cortex of conscious rats
}

Francesco Crespi

Electrochemistry Lab. Medicine Centre, Verona, Italy

Corresponding Author: Francesco Crespi, Electrochemistry Lab. Medicine Centre, Verona, Italy.

Received date: February 26, 2021; Accepted date: March 30, 2021; Published date: April 06, 2021

Citation: Francesco Crespi (2021) Microdialysis in vivo evaluation of the effects of SA-4503, a sigma1 receptor agonist, on the levels of monoamines in the prefrontal cortex of conscious rats. J. Neuroscience and Neurological Surgery. 8(4); DOI:10.31579/2578-8868/164

Copyright: (C) 2021 Francesco Crespi, This is an open-access article distributed under the terms of The Creative Commons Attribution License, which permits unrestricted use, distribution, and reproduction in any medium, provided the original author and source are credited

\begin{abstract}
:
Sigma receptors are widespread in the central nervous system and are differentiated in two subtypes, sigmal and sigma2. In particular, the sigma1 receptor subtype appears to be able to influence biological mechanisms connected with neuro-degeneration. Furthermore, several studies are implicating sigma1 receptor agonists within antidepressant activity.

Evidence of prefrontal cortex abnormalities in clinically depressed subjects have been reported by several works and that monoamines such as serotonin and cathecolamines can be involved in such malfunctions.

Up to now the most of the preclinical work performed to analyze the influence of sigmal receptor agonists upon catecholaminergic and serotoninergic activities in brain areas has been done by means of in vitro as well as ex vivo methodologies.

Here, SA-4503, a selective sigma1 receptor agonist with potential antidepressant activity has been tested in vivo upon dopamine (DA), noradrenaline (NA) and serotonin (5-HT) levels detected by micro-dialysis in the medial Prefrontal Cortex (mPFC) of freely moving rats.

Keywords: sigma1 receptor; SA-4503; medial Prefrontal Cortex, freely moving rats; micro-dialysis; dopamine, noradrenaline and serotonin
\end{abstract}

\section{INTRODUCTION}

Sigma receptors are widespread in the central nervous system and across multiple peripheral tissues. Sigma receptors were initially described in 1976 as opiate receptors. They were successively differentiated in two subtypes, sigma1 and sigma2 [1,2]. More recently it has been shown that these receptors are non-opioid, are trans-membrane proteins and play various purposes in intracellular signaling, apoptosis and metabolic regulation (for a review see ref. 3). Besides, several studies propose that Sigma receptors undergo various functions in psychiatric diseases. It has been shown that sigma receptors and in particular the sigmal receptor subtype is expressed in both neuronal as well as cerebral glia cells and appear to be able to influence biological mechanisms connected with neuro-degeneration [4] Thus, sigmal receptors may be considered as targets for the development of pharmacological approaches to treat various CNS disorders (for a review see ref. 5).

In particular accrued indication are proposing a function for these sigma receptors in antidepressant effects $[6,7]$.

Cerebral cathecolamines as well as serotonin have been implicated in psychiatric diseases induced either by defined genetic etiologies and pathological phenotypes that result in neurodegenerative disorders (for a review see refs $8,9,10$ ).
For what concerns cathecolamines, various experiments, mainly performed in vitro as well as ex vivo, have shown that sigmal receptors are one of the endogenous substrates that are able to antagonize cytotoxicity connected to dopamine activity [11], toxicity that is responsible of apoptosis and therefore can be leading to Parkinson disease [12] i.e. endogenous dopamine can undergo both enzymatic and autooxidation, generating ROS and causing degenerative damage to dopaminergic neurons [13].

Disorder in central noradrenergic transmission in depression has been described $[14,15]$. Mainly a complex alteration of noradrenergic function is observed, most consistent with over-activation of this system (for a review see ref. 16).

The involvement of serotonin in the pathophysiology of depression is suggested by various observations $[17,18]$ and various studies have shown that long-lasting treatments with antidepressants increase 5-HT neurotransmission $[19,20]$.

Magnetic resonance imaging (MRI) and computed tomography (CT) as well as positron emission tomography (PET) and single photon emission computed tomography (SPECT) i.e. structural and functional imaging 
have indicated that the prefrontal cortex, is being directly involved in clinical depression. Indeed these studies have shown evidence of prefrontal cortex abnormalities in clinically depressed subjects i.e. functional imaging studies demonstrate prefrontal lobe hypo-metabolism in primary and secondary depression, with severity of depression often correlating with the degree of frontal inactivity [21, 22, 23].

Up to now the most of the preclinical work performed to analyze the influence of sigmal receptor agonists upon catecholaminergic and serotoninergic activities in brain areas has been done by means of in vitro as well as ex vivo methodologies. In vivo studies have been also performed but mainly by means of electrophysiologic analysis of cell firing in discrete brain areas, with no biochemical evidence of specific neurotransmitter(s) changes [24].

In the present work, the effects of SA-4503, a selective sigmal receptor agonist with potential antidepressant activity [24, 25] has been tested in vivo upon dopamine (DA), noradrenaline (NA) and serotonin (5-HT) levels in the medial Prefrontal Cortex (mPFC) of freely moving rats prepared for micro-dialysis as described earlier [26, 27, 28].

The choice of such selective sigmal receptor agonist was set by the evidence of a high specific uptake of $\left[{ }^{11} \mathrm{C}\right] \mathrm{SA} 4503$ in the brain frontal cortex in ex vivo autoradiography (ARG) and PET studies [29, 30].

\section{METHODS}

A microdialysis implant was applied as described earlier [26, 27] to four groups of male rats ( $\mathrm{n}=10$ each group) that were randomly tested with the vehicle (aCSF, $2 \mathrm{ml} / \mathrm{kg}$ p.o.) and the sigmal agonist at doses 1,3 and 10 $\mathrm{mg} / \mathrm{kg}$. Before (basal levels) and following drug treatments microdialysis samples were collected every 20 minutes during 3 hours.

\section{Animals}

Male adult rats (Wistars, 250-280 g) were supplied by Charles-River (Italy) and kept in temperature- and humidity-controlled rooms $\left(22{ }^{\circ} \mathrm{C}\right.$, $50 \%$ ). All animal procedures were carried out in accordance with the Italian law (Legislative Decree no. 116, 1992) which acknowledges the European Directive 86/609/EEC. In addition, all efforts were made to minimize the number of animals and their suffering accordingly with ref. 31.

The animals were anaesthetized (urethane, $2 \mathrm{~g} / \mathrm{kg}$ i.p.) and then prepared for brain microdialysis in the mPFC (stereotaxic coordinates from ref. 32) as already described $[26,27]$. The treatment with SA-4503 (provided by M's Science Corporation, Kobe, Japan) was performed accordingly with ref. 33. In particular the doses 1,3 and $10 \mathrm{mg} / \mathrm{Kg}$ p.o. were selected for single administration of this sigmal receptor agonist.

\section{Micro-dialysis}

Brain microdialysis is based upon the sampling of cerebral extracellular fluid by means of a cannula built and then surgically implanted into the tissue to be studied as described earlier [26, 27]. Briefly, fiber dialysis membrane $0.2-0.3 \mathrm{~mm}$ in diameter are inserted into a metal cannula and perfused with an iso-osmolar physiological fluid such as artificial cerebral spinal fluid (aCSF).

The outflow dialysate contains the molecules that traverse into the aCSF fluid because of the concentration gradient between the perfusate and the extracellular space. It is collected every 20 minutes and then basal levels of DA, NA and 5-HT in each dialysate are measured by using an HPLC system with electrochemical detection for separation and quantification as described earlier [26, 27].

Formulation of artificial cerebrospinal fluid (aCSF) in mM: $125 \mathrm{NaCl}, 2.5$ $\mathrm{KCl}, 2 \mathrm{CaCl} 2,1 \mathrm{MgCl} 2,25 \mathrm{NaHCO} 3,1.25 \mathrm{NaH} 2 \mathrm{PO} 4,25$ glucose bubbled with $95 \% \mathrm{O} 2,5 \% \mathrm{CO} 2$, then add $2 \mathrm{CaCl} 2$. Filter with a $0.22-\mu \mathrm{m}$ filter apparatus, and store at $4^{\circ} \mathrm{C}$.

\section{Data analysis}

The data obtained from all the experiments were converted to percent from basal values and analyzed with STATISTICA software version 6.0 using repeated-measures ANOVA, with treatment and time as main factors. The Fisher LSD test was used as post hoc to evaluate significant differences between mean values produced by drug treatments versus controls (vehicle treatment) at each time point. Statistical significance was set at a probability level of $\mathrm{p}<0.05$.

\section{RESULTS}

The in vivo data collected in the mPFC following the treatment with SA4503 showed that:

- the dose $1 \mathrm{mg} / \mathrm{kg}$ was unable to modify significantly any of the three signals monitored

- the doses $3 \mathrm{mg} / \mathrm{kg}$ and $10 \mathrm{mg} / \mathrm{kg}$ appeared to be able to modify DA in a rather dose - dependent manner and 5-HT levels in a similar manner (see figure 1 middle and bottom). In particular, concerning NA, the highest dose was able to increase significantly the related electrochemical signal up to approx. $200 \%$ over the control values within $80-100 \mathrm{~min}$ (figure1 top). The values of DA increased up to $300 \%$ of controls following the middle and highest dose within 20-30min and up to approx. $350 \%$ of controls within $80-100 \mathrm{~min}$ (figure 1 middle). The values of $5-\mathrm{HT}$ increased up to approx. $300 \%$ of controls following 3 and $10 \mathrm{mg} / \mathrm{Kg} \mathrm{SA}$ 4503 within $20-30 \mathrm{~min}$ and up to approx. $350 \%$ within $80-90 \mathrm{~min}$. Successively, the effect of the $3 \mathrm{mg} / \mathrm{kg}$ dose tended to reduce while the highest dose was determining a further increase of 5-HT levels up to approx. $400 \%$ of controls within 180min (figure 1 bottom). 

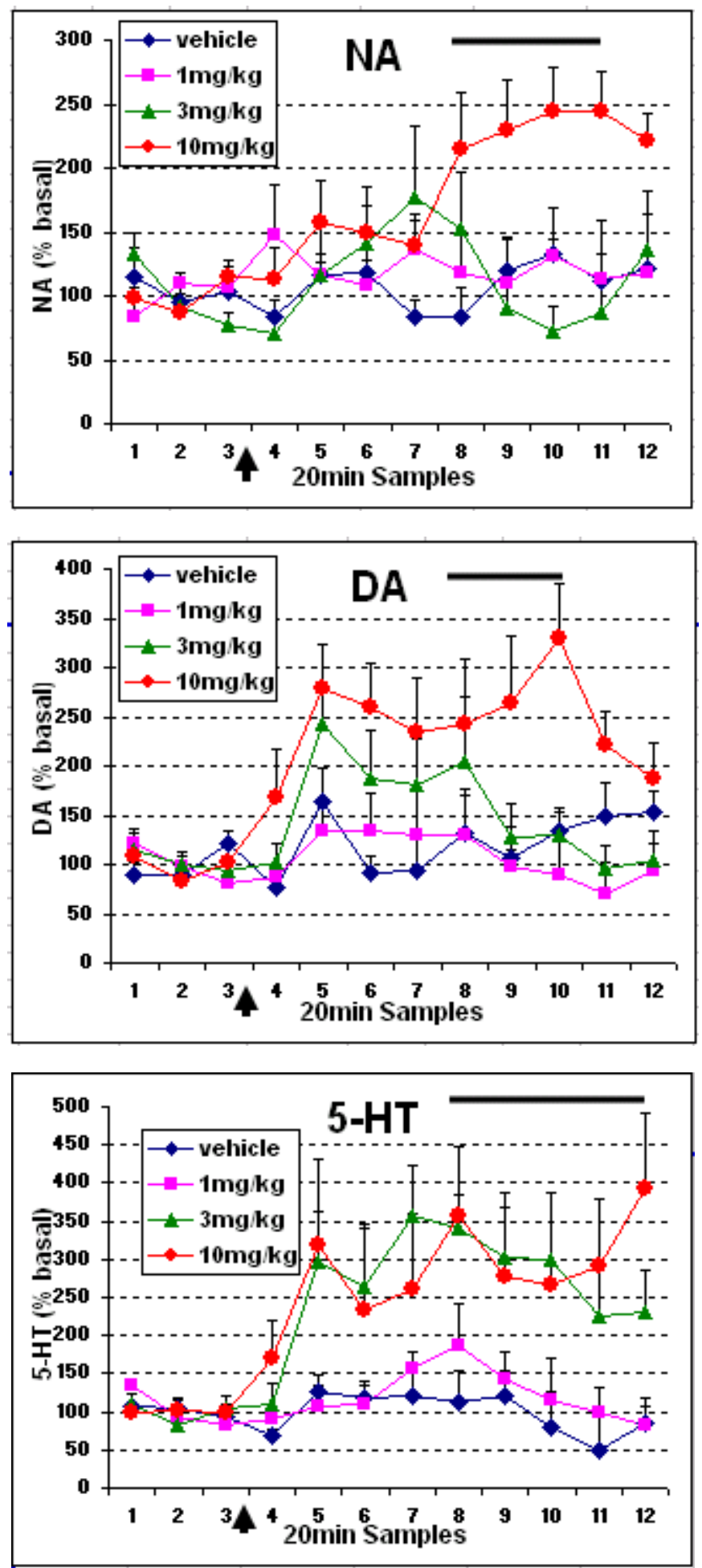

Figure 1 shows the effect of vehicle (aCSF $2 \mathrm{ml} / \mathrm{kg}$ p.o., $\mathrm{n}=10$ ) and that of the sigma1 receptor agonist SA-4503 at doses $1,3 \mathrm{and} 10 \mathrm{mg} / \mathrm{kg}$ ( $\mathrm{n}=10$ each dosage) upon extracellular levels of NA, DA and 5-HT collected within the mPFC of conscious rats.

Before (basal levels) and following each treatment (arrow) microdialysis samples were collected every 20 minutes during 3 hours. In each panel, black solid line indicates statistical significance set at a probability level of $\mathrm{p}<0.05$.

\section{DISCUSSION}

The present in vivo e experiments performed in conscious animals have shown that treatment with the sigmal receptor agonist SA-4503 is followed by increase of the three monoamines monitored in the $\mathrm{mPFC}$. In 
particular, the dose 3 and $10 \mathrm{mg} / \mathrm{Kg}$ resulted in significant increase of the electrochemical signal related to 5 -HT while the dosage of $10 \mathrm{mg} / \mathrm{Kg}$ in that of NA and DA. This is in accord with previous work showing a maximum effect of $10 \mathrm{mg} / \mathrm{Kg}$ dose of SA-4503 upon electrophysiological, morphological and behavioural parameters monitored in anaesthetized as well as behaving rodents [33]. Furthermore, the present data is qualitatively in line with some literature reports about the putative capability of sigmal receptor agonist to facilitate DA release in prefrontal cortex [34, 35].

In addition, evidence for an improved extracellular level of NA in this area further support the implication of catecholamines within the sigma1 receptor agonists influence in such brain region, and in particular their positive effect in behavioural models of depression such as the tail suspension [36, 37] and the forced swimming test [38, 39].

Taken together with the electrophysiological, morphological and behavioural observations reported in ref. 33 in which it appears that functional changes following SA-4503 treatment occurred within a short time-frame (2-3 days) all these data provide both functional and behavioural evidence that this compound has an important antidepressant potential; moreover they suggest that this antidepressant potential might have a rapid onset of action.

Concerning serotonin, several works suggest that sigmal receptors are involved in the active mechanisms of selective serotonin reuptake inhibitors (SSRIs) so that sigmal receptor agonists are proposed as potential therapeutic drugs for the treatment of cognitive impairment in schizophrenia, psychotic depressions well as neurodegenerative disorders (for a review see refs 40, 41). Furthermore, it has been shown that sigma ligands are able to speedily produce an increase in 5-HT firing activity recorded in the dorsal raphe nucleus (DRN) with a more rapid and robust effect than the vast majority of known antidepressant medications [3, 42].

The interaction of sigma receptors and neurotransmitters is complex, and although a lot of work has been done in this field, most work is done in in vitro (for a review see ref. 3 ). In the attempt to help in elucidating such interaction, the present observations are proposing a rapid significant positive influence of SA-4503 upon neuroamines monitored in vivo in the $\mathrm{pFC}$, and in particular on those involved in psychiatric diseases $[8,9,10]$, thus strengthening the argument for sigma receptor's role in depression and proposing sigma ligands as potential antidepressant with a rapid onset of action.

\section{Acknowledgement to:}

Francesco Congestri', Chiara Lazzarini for technical support

\section{REFERENCES}

1. Martin, W., Eades, C., Thompson, J., huppler, R., Gilbert, P. (1976). The effects of morphine- and nalorphine-like drugs in the nondependent and morphine-dependent chronic spinal dog. J. Pharmacol. Exp. Ther., 197, 517532.

2. Quirion, R., Chicheportiche, R., Contreras, P., Johnson, K., Lodge, D., Tam, S., Woods, J., Zukin, S. (1987).
Classification and nomenclature of phencyclidine and sigma receptor sites. Trends Pharmacol. Sci., 10, 444-446.

3. CG. Rousseaux, SF. Greene. Sigma receptors $[\sigma$ Rs]: biology in normal and diseased states. Journal of Receptors and Signal Transduction 36, 2016 - Issue 4, 327388.

4. L. Nguyen, BP. Lucke-Wold, SA. Mookerjee, JZ. Cavendish, MJ. Robson, AL. Scandinaro, RR. Matsumoto. Critical review Role of sigma-1 receptors in neurodegenerative diseases. Journal of Pharmacological Sciences Volume 127, Issue 1, 2015, 17-29.

5. DA. Ryskamp, S. Korban, V. Zhemkov, N. Kraskovskaya, I. Bezprozvanny. Neuronal Sigma-1 Receptors: Signaling Functions and Protective Roles in Neurodegenerative Diseases Front. Neurosci., 2019, 13, 862, 1-20.

6. JE. Bermack, G. Debonnel The Role of Sigma Receptors in Depression. Journal of Pharmacological Sciences 97 (2005), No. 3 p.317.

7. JA.Fishback, MJ.Robson,Yan-TongXu, RR.Matsumoto Sigma receptors: Potential targets for a new class of antidepressant drug Pharmacology \& Therapeutics 127, Issue 3, 2010, 271-282.

8. MA. Kurian, P. Gissen, M. Smith, SJR. Heales, PT. Clayton. The monoamine neurotransmitter disorders: an expanding range of neurological syndromes. THE LANCET Neurology,10, Issue 8, 2011, 721-733.

9. J. Dean, M. Keshavan The neurobiology of depression: An integrated view. Asian Journal of Psychiatry, 27, 2017, 101-111.

10. Ng, J., Papandreou, A., Heales, SJ, MA. Kurian. Monoamine neurotransmitter disorders-clinical advances and future perspectives. Nature Reviews Neurology 11, 567-584 (2015).

11. Sambo, D.O., Lin, M., Owens, A. et al. The sigma-1 receptor modulates methamphetamine dysregulation of dopamine neurotransmission. Nat. Commun. 8, 2228 (2017).

12. Dben-Shachar, R. Zuk, H. Gazawi, P. Ljubuncic. Dopamine toxicity involves mitochondrial complex I inhibition: implications to dopamine-related neuropsychiatric disorders. Biochemical Pharmacology 67, Issue 10, 2004, 1965-1974.

13. T. Mori, T. Hayashi, T.P. Su. Compromising sigma-1 receptors at the endoplasmic reticulum render cytotoxicity to physiologically relevant concentrations of dopamine in a nuclear factor- $\mathrm{B} / \mathrm{Bcl}-2-d e p e n d e n t$ mechanism: potential relevance to PD. Journal of Pharmacology and Experimental Therapeutics 2012, 341 (3) 663-671.

14. Leonard, B. E. (1997). The role of noradrenaline in depression: A review. Journal of Psychopharmacology, 11(Suppl 4), S39-S479.

15. B, Haenisch, H. Bönisch. Depression and antidepressants: Insights from knockout of dopamine, serotonin or noradrenaline re-uptake transporters. Pharmacology \& Therapeutics 129, Issue 3, 2011, 352-368. 
16. KJ. Ressler, CB. Nemeroff. Role of serotonergic and noradrenergic systems in the pathophysiology of depression and anxiety disorders. Depression \& Anxiety12, IssueS1 2000, 2-19.

17. Delgado, P.L. (2000). Depression: the case for a monoamine deficiency. J. Clin. Psychiat. 61, (Suppl 6): 711.

18. Cowen, P. J., \& Browning, M. (2015). What has serotonin to do with depression?. World psychiatry : official journal of the World Psychiatric Association (WPA), 14(2), 158160.

19. Blier P, de Montigny C. Current advances and trends in the treatment of depression. Trends Pharmacol Sci. 199415(7):220-226.

20. F. Artigas. Serotonin receptors involved in antidepressant effects. Pharmacology \& Therapeutics 137, Issue 1, 2013, 119-131.

21. MS. George, TA. Ketter, RM. Post. Prefrontal cortex dysfunction in clinical depression. Depression 2, Issue2, 1994, 59-72.

22. DA. Seminowicz, HS. Mayberg, AR. McIntosh, K. Goldapple, S. Kennedy, Z. Segal, S. Rafi-Tari. Limbicfrontal circuitry in major depression: a path modeling metanalysis. NeuroImage 22, Issue 1, 2004, 409-418.

23. BP. Godsil, JP. Kiss, M. Spedding, TM. Jay. The hippocampal-prefrontal pathway: The weak link in psychiatric disorders? European Neuropsychopharmacology 23, Issue 10, 2013, 11651181.

24. G. Lucas, VV. Rymar, AF. Sadikot, G. Debonnel. Further evidence for an antidepressant potential of the selective $\delta_{1}$ agonist SA 4503: electrophysiological, morphological and behavioural studies. International Journal of Neuropsychopharmacology 11, Issue 4, 2008, 485-495.

25. K. Matsuno S. Mita SA4503: A Novel Sigma1 Receptor Agonist. CNS Drug Reviews 4, Issue1, 1-24, 1998.

26. Sharp T, Bramwell SR, Clark D, Grahame-Smith DG. (1989) In Vivo Measurement of Extracellular 5Hydroxytryptamine in Hippocampus of the Anaesthetized Rat Using Micro-dialysis: Changes in Relation to 5Hydroxytryptaminergic Neuronal Activity. J Neurochem 53, 234-240.

27. Crespi, F., Wright, I.K., Möbius, C. Isolation rearing of rats alters release of 5-hydroxytryptamine and dopamine in the frontal cortex: an in vivo electrochemical study. Exp Brain Res 88, 495-501 (1992).

28. Crespi F. Serotonin (5-HT) release in the hippocampus following various conditions and treatments affecting 5HT receptors has been studied in vivo mainly by the means of brain micro-dialysis: A review. Biology, Engineering and Medicine, 2017, 2(4): 1-4

29. K. Kawamura, K. Ishiwata, H. Tajima, Shin-IchiIshii, K. Matsuno, Y. Homma, M. Senda. In vivo evaluation of $\left[{ }^{11} \mathrm{C}\right] \mathrm{SA} 4503$ as a PET ligand for mapping CNS sigma ${ }_{1}$ receptors. Nuclear Medicine and Biology 27, Issue 3, 2000, Pages 255-261.

30. Elsinga, P., Tsukada, H., Harada, N., Kakiuchi, T., Kawamura, K., Vaalburg, W., Kimura, Y., Kobayashi, T. and Ishiwata, K. (2004), Evaluation of $\left[{ }^{18} \mathrm{~F}\right]$ fluorinated sigma receptor ligands in the conscious monkey brain. Synapse 52, 29-37.

31. Crespi F, Congestri F, Formenti F. Near infrared spectroscopy (NIRS) to attain reduction-refinementrespect, the three Rs towards ANIMAL WELFARE in preclinical research. Neurology \& Neurological Sciences Open Access. 2019; 2(1): 1008. ISSN: 2641-0362.

32. Paxinos G. Watson C. (1986). The Rat Brain in Stereotaxic Coordinates (2nd edn). New York: Academic.

33. G. Lucas, VV. Rymar, AF. Sadikot, G. Debonnel. Further evidence for an antidepressant potential of the selective $\delta_{1}$ agonist SA 4503: electrophysiological, morphological and behavioural studies. International Journal of Neuropsychopharmacology 11, Issue 4, 2008, 485-495.

34. GA.Gudelsky. Effects of $\sigma$ receptor ligands on the extracellular concentration of dopamine in the striatum and prefrontal cortex of the rat. European Journal of Pharmacology 286, Issue 3, 1995, 223-228.

35. V. Francardo, F. Bez, T. Wieloch, H. Nissbrandt, K. Ruscher, MA. Cenci, Pharmacological stimulation of sigma-1 receptors has neurorestorative effects in experimental parkinsonism, Brain 137, Issue 7, 2014, 1998-2014.

36. Ukai, M., Maeda, H., Nanya, Y., Kameyama, T. \& Matsuno, K. (1998). Beneficial effects of acute and repeated administrations of $\sigma$ receptor agonists on behavioral despair in mice exposed to tail suspension. Pharmacol. Biochem. Behav. 61, 247-252.

37. van Broekhoven, F., Verkes, R.J. Neurosteroids in depression: a review. Psychopharmacology 165, 97-110 (2003).

38. Porsolt RD. (1981) Behavioral despair. In: Enna SJ, Malick JB, Richelson E (eds) Antidepressants: neurochemical, behavioral, and clinical perspectives. Raven Press, New York, pp 121-139)

39. Skuza, G.; Rogóż, Z. A potential antidepressant activity of SA4503, a selective $\sigma 1$ receptor agonist, Behavioural Pharmacology 2002 - Volume 13 - Issue 7 - p 537-543.

40. Niitsu, T; Iyo, M.; Hashimoto, K. Sigma-1 Receptor Agonists as Therapeutic Drugs for Cognitive Impairment in Neuropsychiatric Diseases Current Pharmaceutical Design 18, Number 7, 2012, pp. 875-883.

41. Penke, B.; Fulop, L.; Szucs, M.; Frecska, E. The Role of Sigma-1 Receptor, an Intracellular Chaperone in Neurodegenerative Diseases. Current Neuropharmacology 16, 1, 2018, pp. 97-116. Bentham Science Publishers

42. Bermack, J.E. Debonnel, G. (2001) Modulation of serotonergic neurotransmission by short- and long-term treatments with sigma ligands. British Journal of Pharmacology 134: 691-699. 
(c) (i)

This work is licensed under Creative

Commons Attribution 4.0 License

To Submit Your Article Click Here: Submit Manuscript

DOI: $10.31579 / 2578-8868 / 164$
Ready to submit your research? Choose Auctores and benefit from:

* fast, convenient online submission

* rigorous peer review by experienced research in your field

* rapid publication on acceptance

* authors retain copyrights

* unique DOI for all articles

* immediate, unrestricted online access

At Auctores, research is always in progress.

Learn more www.auctoresonline.org/journals/neuroscience-andneurological-surgery 